\title{
THE DEADLOCK OF THE EU BUdGET: AN ECONOMIC ANALYSIS OF WAYS IN AND WAYS OUT
}

\author{
CHARLES B. BLANKART \\ CHRISTIAN KIRCHNER
}

CESIFo WORKING PAPER NO. 989

CATEGORY 2: Public CHOICE

JULY 2003

Presented at CESifo Conference “A CONSTitution For the EU” February 2003

An electronic version of the paper may be downloaded

- from the SSRN website:

- from the CESifo website:

www.SSRN.com

www.CESifo.de 


\title{
THE DEADLOCK OF THE EU BUDGET: AN ECONOMIC ANALYSIS OF WAYS IN AND WAYS OUT
}

\begin{abstract}
Most of the EU budget is spent on redistribution. Large sums of money are transferred from the member state governments to Brussels and back to these governments. Some member states end up as net receivers and some as net payers. Most economists agree that the resources of the budget should be reallocated from redistribution towards the provision of more Union-wide public goods. While such appeals have been made for years, little change has been observed. We want to explain why. We propose to distinguish two periods. In the early years of the Community, some larger member states or coalitions of member states were able to credibly threaten to terminate membership if their claims on budgetary resources were not fulfilled. Their activity has created a redistributive status quo to which, in the second period, the budgetary rules of the Treaty were applied. It is shown that the combination of the Council's qualified majority rule on the expenditure side and the unanimity rule on the revenue side and on the programs are largely responsible for creating a deadlock in the status quo with large redistribution and few Union-wide public goods. In order to break the deadlock, a complementary budget procedure is proposed on the basis of voting by veto.
\end{abstract}

JEL Code: H31, D78, H87.

Charles B. Blankart

Humboldt-Universität zu Berlin

Wirtschaftswissenschaftliche Fakultät

Spandauer Strasse

10178 Berlin

Germany

charles@blankart.net
Christian Kirchner

Humboldt-Universität zu Berlin

Wirtschaftswissenschaftliche Fakultät

Spandauer Strasse

10178 Berlin

Germany

The authors are indebted to Dennis Mueller and Ludger Schuknecht for helpful comments. 
(preliminary draft, May 28, 2003 / please do not cite without permission of the authors)

\section{The Normative View of the EU Budget and Its Positive Alternative}

EU spending is dominated by redistribution. Large sums of money are transferred from the member states to Brussels and back to the member states. Only little (about 15 percent of the budget) is spent for Union wide public goods. ${ }^{1}$ There is a widespread view that EU spending is inefficient. Redistribution is said to be excessive while the provision of Union wide public goods is held to be too small comparatively. Many economists believe that a reallocation of the budget would generate welfare gains. Guido Tabellini illustrates the common belief:

"From the perspective of cost and benefit analysis, it seems obvious that there would be large payoffs to more central provision of public goods in the areas of defence foreign policy, and of aspects of internal security, border patrols, immigration policy. The abolition of borders between EU countries carries with it the need to centralise aspects of law enforcement against organised crime. Moreover the recent terrorist attacks have made it absolutely clear that the challenges in these areas are global and require a co-ordinated European response. The positive spill-over effects and the economies of scale for foreign and defence policy, international security, border patrols and immigration policy are very large. ... Currently the EU budget is mainly devoted to finance the redistributive programs of the EU.... Now the whole discussion on the EU budget only concerns who gains and who loses, and in particular which countries are net beneficiaries or net payers, and by how much. No attention is paid as to

\footnotetext{
${ }^{*}$ The authors are indebted to Dennis Mueller and Ludger Schuknecht for helpful comments.

${ }^{1}$ European Commission, Haushaltsvademekum 2000, p 31. Expenditures for research, external activities and administration (in relation to total expenditures, 2001) are regarded as contributions to unionwide public goods while member state specific expenditures have been defined as non-unionwide.
} 
whether the money is well spent for the average European tax payer, or whether reallocations across alternative programs are desirable. Enlargements, with the large disparities between rich and poor countries, will make the political debate on the EU budget a nightmare." (Tabellini, 2002, pp. 17-19)

Though there are good arguments supporting Tabellini's view, some questions remain: Why is there so much redistribution? Why does the European Union as an institution that has been founded for promoting free exchange in a common market spend most of its budget on redistribution? And why is redistribution so persistent? Why are some member states consistent net payers and others consistent net receivers? All these questions cannot be answered by a cost benefit analysis of the traditional public finance type. It requires a rigorously positive analysis of the incentives, costs and constraints of political decision making.

Our analysis starts from the theory of incomplete contracts as developed for constitutions by Buchanan (1975), Brennan and Buchanan (1985) and others. Its purpose is the design of rules at the contractual level which will be executed later at on the post-contractual level. While decisions at the contractual level may be unanimous, their later execution may cause problems. We shall distinguish two aternatives:

1. Some decisions made on the contractual level do not require further discussion and decision on the post-contractual level; for the rights and duties of the parties have been reasonably well specified. The contract has simply to be executed. Possible misinterpretations of the terms of contract which may emerge later on are not reconsidered in the political process, but by courts. This holds in particular for contractual redistribution, i.e. redistribution as predesigned in the contract, which can take place according to the agreed upon rules.

2. It has to be anticipated on the contractual level, however, that some contractual provisions are incomplete and that new issues will emerge in the post-contractual stage. Therefore it has to be agreed on the contractual level how to decide when such issues come up. The later application and the enforcement of these contractual rules is often not called into question. It is simply assumed that the decisions according to these rules will be binding because the rules themselves have been agreed upon unanimously.

This assumption will be relaxed here. The rules to settle postcontractual issues will, in general, not generate unanimously accepted outcomes. There will be winners and losers. The latter 
may reject the outcomes if they have the power to threaten to terminate the contract. But their threat has to be credible. In this paper, we make the simple assumption that a threat is only credible for the larger partners or for a coalition of partners without whom the contract cannot be maintained and that the credibility of threat is strong in the early stages of a contractual arrangement, as long as the ties of cooperation which evolve under the roof of the contract are still loose. Therefore there is not much to lose by terminating memberhip. Through time, however, these ties will become more intense, the costs of exit will rise, which makes the threat of exit less credible, and the post-contractual decisions following from the application of the constitutional rules will become binding.

This basic reasoning will now be applied on the budget of the European Union. In the Treaty of Rome of 1957 we can find contractual rules of redistribution of type 1 which are applied without further decisions at the post-contractual level, and rules of type 2 which require redistributive decisions at the post-contractual level. Had the Treaty been designed as a fully complete contract, postcontractual redistribution would not be an issue. But the Treaty of Rome was typically an incomplete contract (see upper part of figure 1). Therefore postcontractual decisions on redistribution had to be expected. Redistribution did, however, not only take place according to these agreed upon rules, but also through threat.

Rules were dominated by threat in particular in the early decades of the existence of the Community (see middle range of figure 1). Member state governments which had alternative policy options and who were able to harm the other member states by terminating their membership used threatening power to enforce their distributive goals in the budget. With progressing cooperation in the Common Market, however, threats became increasingly less credible. It has become obvious that the loss from terminating membership would be too large. Therefore threat as an instrument of influencing the budget was increasingly substituted by the formal rules of the Treaty (see lower range of figure 1).

These rules, however, are far from perfect. They separate the expenditure side of the budget from the revenue side and therefore generate opposing coalitions, on either side of the budget. The expenditure side is dominated by net receivers, the revenue side by net payers, and both goups exert veto power. The likely result is that of a budget deadlock dominated by redistribution with fixed allocation of benefits and burdens per member state. Union wide public goods are unlikely to be provided in a larger amount, as those who benefit from redistribution in the status quo have to give up their priviledges to finance these 
public goods and those who pay for the budget are reluctant to pay more money because they cannot earmark their contibutions for the provision of public goods. To put it differently: The allocation of burdens and benefits, as it came out of the threatening period, generated a new re-distributive status quo which has been preserved or locked in thereafter and which is likely to continue after Eastern accession. A change towards more Union wide public goods is unlikely to be achieved under the present rules. We rather believe that a new additional set of rules is required for allowing decisions on public goods.

Figure 1: Budgetary Rules and Budgetary Outcomes 1957-2000

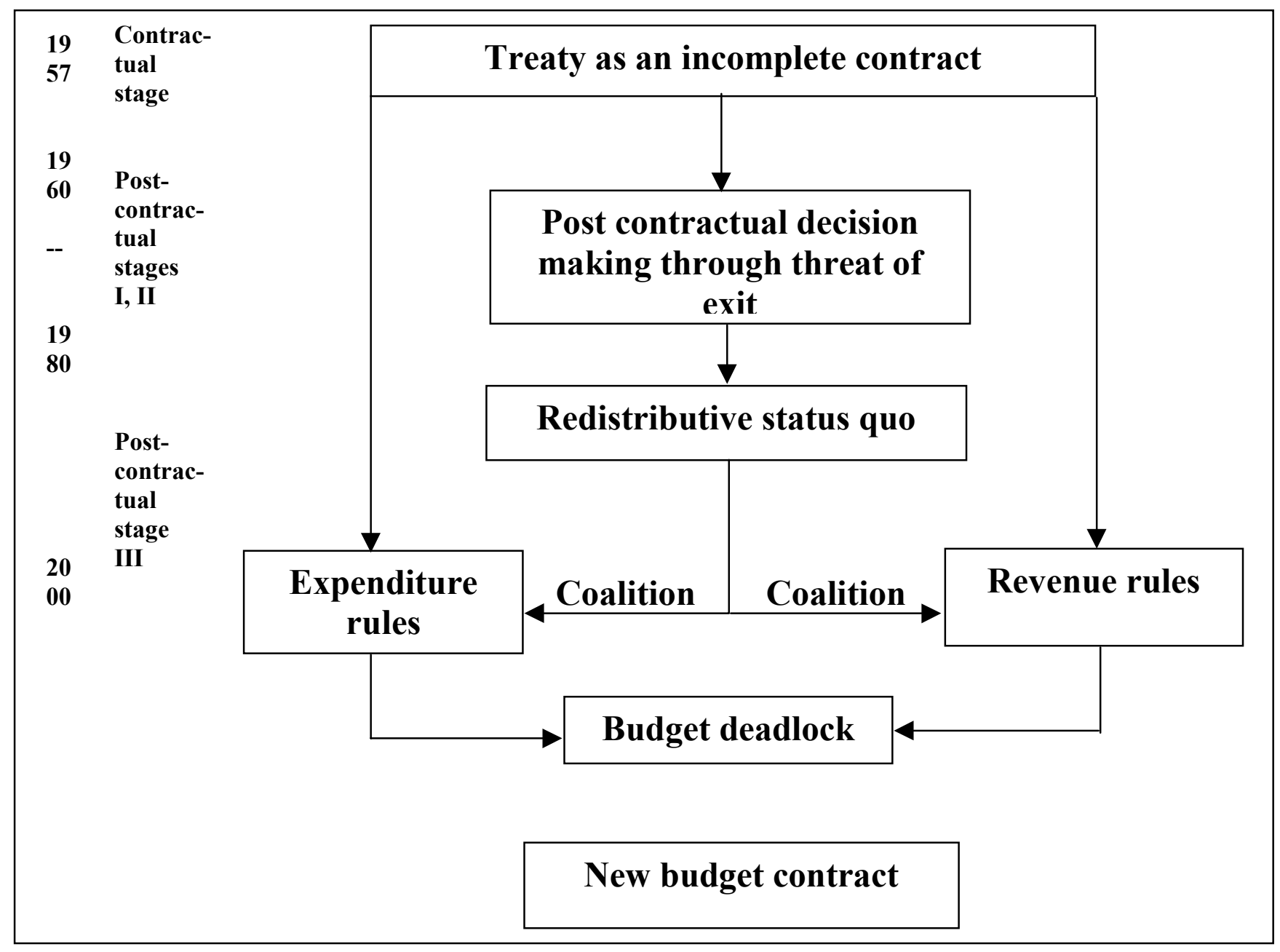

Source: Own interpretation

In the literature one can find roughly three approaches to the budgetary process in the European Union. A first group of authors concentrates on a description of 
the design of the budgetary rules and on the decisions which have been taken: Messal (1989, 1991), Messal and Klein (1993), Peffekoven (1994), Strasser (1991) EU Commission (1995) and Lienemeyer (2002). Though this literature only describes what happened, not why it happened, it is very valuable; for it serves as a "data base" on which our hypotheses have to rely. A second group of authors argue that "power politics dictate the EU's budget" (Baldwin et al., 1997 , p. 157). We have benefited a lot from their work whose view we share. But we should be able to predict more precisely when and what power counts. A third group of authors such as Widgrén (1994), Hosli (1996), Peters (1996), Raunio and Wiberg (1998) try to assess mainly voting power in the Council and to predict the changes of power when the Union is enlarged towards Eastern Europe. But they do not confront their predictions with the decisions taken on budget allocations. There is still a gap, as far as we know, between budget decision making rules and budgetary outcomes. Vaubel (2001, p. 36) has mentioned recently the problem of the different types of rules and coalitions, one on the expenditure and one on the revenue side, without, however, deepening his observation. In this paper we want to make a contribution to this problem.

Before going into the analysis of the distributional consequences of these rules and the emergence of the budgetary deadlock in part III of the paper, we want first to give a break down of the actual budget incidence in part II. In part IV we widen the scene and discuss new budgetary procedures to overcome the deadlock. Conclusions follow in section V.

\section{The Budget Incidence Today}

The compilation of data on the incidence of the EU budget is not simply a statistical problem. These data represent a political issue which could be a subject of a public choice analysis of its own. Politicians, in general, tend to avoid talking about money. They prefer to give great speeches on the future of the European Union and its achievements rather than to talk about its financing. The budget implying the question of who has to pay how much and for whom is postponed as long as possible in the political process in order to maintain the impression of harmony among the political fellows. In the rhetoric it is said that the budget is too small to be of major relevance. It is true that in the early years of the European Economic Community the budget was only about 80 million Euro. But it has risen by about factor of a 1000 to nearly 90 billion Euro in 2001. Even today, the budget costs are only about 1,13 percent of EU GNP in 2000 (see figure 1). But 1,13 percent is still a remarkable sum of money when compared to the resources of a smaller member state, e.g. of Denmark, whose total government sector including social security is about the same absolute size. Despite these facts, the problem of redistribution is often put aside. 


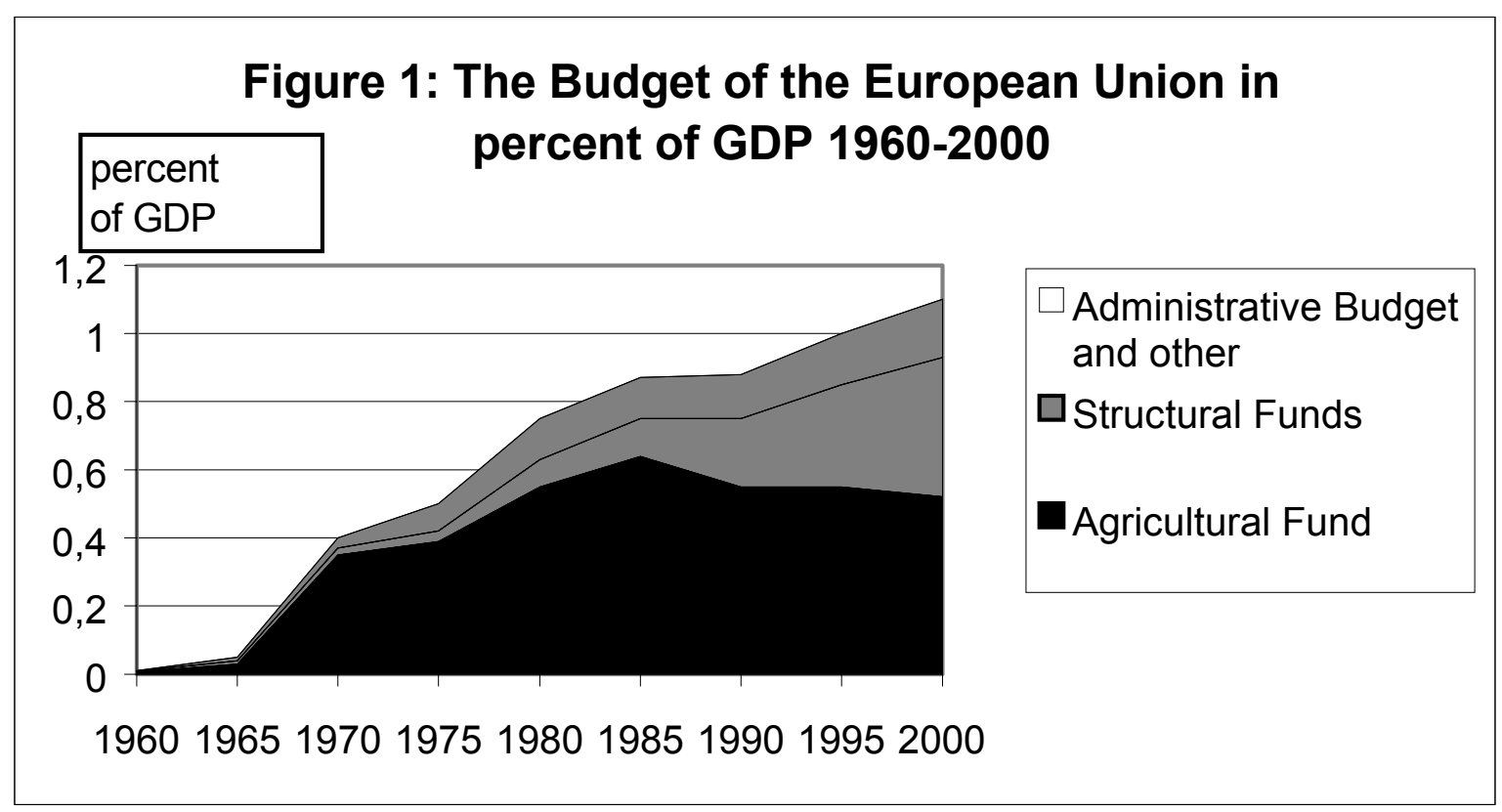

Source: From data of the European Commission

The general distaste of talking about redistribution and who pays for whom is also reflected in the Commission's policy of not publishimg data on the net incidence of the EU budget. They argue that statistical numbers could not be allocated to particular Member States and that they did not reflect the true benefits derived from EU membership (EU Commission 2001). Only after the insistence of the German government, the Commission gave in and has started to publish data since 1994 (Stegarescu, 1999).

In its statistical-break down the Commission publishes only the so-called operative expenditures - about 90 to 95 per cent of the budget -. It is said that only those have a re-distributive effect which could be allocated to member states (EU Commission 2001). Operative expenditures encompass mainly expenditures for the Common Agricultural Policy (CAP) and for the structural policy. The assumption presumably is that these budget allocations can be valued one-to-one between member states. The willingness to pay 1 Euro is for the contributing Member State the same as the willingness to accept 1 Euro for the receiving Member State neglecting rent seeking costs and welfare costs of raising funds. Even if we accept this assumption, the calculations remain distorted when the Commission confronts these expenditures with each Member State's total contributions to the Union. Since contributions are larger than operative expenditures, too many Member States end up as apparent net contributors. 
To put it differently: If we would add the money equivalent of what the Commission calls "the advantages accruing to the Member States from the Union" (EU Commission 2001, p. 6) to each Member State's receipts, each of them might turn out to be a net receiver. But what are these public good values shared by all members, in particular what is the value of the Common Market protected by the Council, the Commission and the European Court of Justice? We assume that the total willingness to pay for the maintenance of the Common Market and for the other public goods by the European citizens represented by their national governments is at least as large as their costs as reflected in the administrative budget and that each government's willingness to pay can be approximated by the member state's share of intra-community trade. The intuitive reason is as follows: large member states benefit from the Common Market because of their large volume of intra-community trade and small member states benefit because they may have above average intra-community export quotas relative to their GNP in order to benefit from the division of labour in the larger market. In table 1 we have added the administrative expenditures allocated on each Member State according to this rule to the operative expenditures as calculated by the European Commission. These were then subtracted from each member state's contributions to the common budget yielding the total net payer/net receiver position of each member state. A minus mark means that the Member State is a net payer.

It turns out that Germany, the Netherlands, Austria, Sweden and the UK are net payers, while the remaining ten member states are net receivers in the year 2000. Germany is by far the largest net contributor not only in the 1990s as documented in the table, but, as sparse available data seem to indicate, also back to the late 1960s (see e.g. tables 3 and 4 below).

There are a number of statistical problems behind these data which we shall not discuss here. But it is astonishing to see that no less than six institutions calculate and publish data on member states' net contributor/receiver positions and that all of them come to similar results though their methodologies and reasonings may be different. ${ }^{2}$

Germany's persistent net payer position has led to substantial irritation in the political discussion. Normative and positive arguments are intertwined which does not help to clarify the issue. Some say that Germany is a large, indeed the largest country, and among the richest Member States (number 3 in per capita income) and that it must be a net contributor for its mere size and income level. But when we take France and the Benelux states together, they aggregate to similar size and income levels, but their aggregated net contribution is nearly

\footnotetext{
${ }^{2}$ Those are: EUROSTAT, the European Court of Auditors, The EU Commission, the Federal Ministry of Finance in Germany, the Ministry of Finance of the Netherlands and the Deutsche Bundesbank (Stegarescu, 2001). For a critival review of the concept of net payer position see: Milbrandt (2000 pp. 42-46).
} 
zero. Taking alternatively the UK and the Benelux states together, we come to an aggregated net payer position, but it is not even half of the size of Germany's net contribution in 2000. Others argue that one should not look at the relative small amounts of net payments, but rather at the gross payments of the whole budget because only the latter reflect the whole benefit of the EU agricultural and structural policies. But the question remains why redistribution requires large gross payments first, before net payments come out. Finally it is said that larger time spans have to be considered and that figures have to be calculated per capita. But the result does not change. Germany remains the largest net payer with 750 EUR per capita from 1994/95 up to 2000 followed by Sweden with 502 EUR per capita. Further net payers are Austria, the Netherlands and the United Kingdom while Italy and France manage to just break even.

Whilst Germany's large net payments may anger the German tax payer, they are of little analytical interest as such. What matters from a public choice point of view is rather: what are the causes creating permanent net payer positions on the one hand and net receiver positions on the other? Why are some Member States destined to become net payers while others have the privilege to remain net receivers? 
Table 1: Net receipts from the EU Budget $1994-2000$ in million ECU/ Euro

\begin{tabular}{|c|c|c|c|c|c|c|}
\hline & Germany & $\begin{array}{l}\text { lgium } \\
\text { IX. }\end{array}$ & $\begin{array}{l}\text { Denma } \\
\text { rk }\end{array}$ & $\begin{array}{l}\text { Finlan } \\
d\end{array}$ & France & Greece \\
\hline 1994 & $-9630,7$ & 597,5 & 554,2 & 0,0 & $-441,4$ & 4062,3 \\
\hline 1995 & $-10389,2$ & 1081,2 & 644,9 & 14,5 & $-210,9$ & 3654,4 \\
\hline 1996 & $-9642,6$ & 646,8 & 415,6 & 157,5 & $-182,0$ & 4091,7 \\
\hline 1997 & $-9794,1$ & 232,3 & 280,4 & 128,6 & $-645,3$ & 4416,1 \\
\hline 1998 & $-7172,7$ & 188,7 & 154,3 & $-10,6$ & $-108,6$ & 4798,6 \\
\hline 1999 & $-7578,1$ & 359,6 & 279,4 & $-102,0$ & 859,5 & 3888,8 \\
\hline 2000 & $-7229,9$ & 558,4 & 402,0 & 376,6 & 200,5 & 4496,7 \\
\hline Total net payments: & $-61437,3$ & 3664,5 & 2730,9 & 658,7 & $-528,1$ & 29408,5 \\
\hline Population in & 82052 & 10602 & 5284 & 5140 & 58609 & 10499 \\
\hline $\begin{array}{l}\text { median year } 1997 \\
\text { (in 1000): }\end{array}$ & & & & & & \\
\hline $\begin{array}{l}\text { Total net payments } \\
\text { per capita (in Eur.): }\end{array}$ & $-748,76$ & 345,64 & 516,83 & $\begin{array}{r}128,1 \\
6\end{array}$ & $-9,01$ & 2801,07 \\
\hline
\end{tabular}

\begin{tabular}{|c|c|c|c|c|c|c|}
\hline & $\begin{array}{c}\text { UK \& } \\
\text { Northern }\end{array}$ & $\begin{array}{c}\text { Irelan } \\
d\end{array}$ & Italy & $\begin{array}{c}\text { Netherla } \\
\text { nds }\end{array}$ & Austria & $\begin{array}{c}\text { Portu } \\
\text { aal }\end{array}$ \\
\hline 1994 & 2157,4 & $\begin{array}{c}2086, \\
2\end{array}$ & $\begin{array}{c}- \\
1010, \\
6\end{array}$ & 244,2 & 0,0 & $\begin{array}{c}2112, \\
2\end{array}$ \\
\hline 1995 & $-2080,6$ & $\begin{array}{c}2201 \\
5\end{array}$ & 461,0 & $-48,6$ & $-539,4$ & $\begin{array}{c}2696, \\
8\end{array}$ \\
\hline 1996 & 178,2 & $\begin{array}{c}2543 \\
0\end{array}$ & $\begin{array}{c}1352, \\
3\end{array}$ & $-701,7$ & $-28,6$ & $\begin{array}{c}2971 \\
5\end{array}$ \\
\hline 1997 & 403,2 & $\begin{array}{c}2955 \\
3\end{array}$ & 219,7 & $-490,4$ & $-551,4$ & $\begin{array}{c}2849, \\
8\end{array}$ \\
\hline 1998 & $-3062,1$ & $\begin{array}{c}2513 \\
0\end{array}$ & $\begin{array}{c}- \\
1007 \\
4\end{array}$ & $-964,8$ & $-391,6$ & $\begin{array}{c}3160, \\
1\end{array}$ \\
\hline 1999 & $-2265,4$ & $\begin{array}{c}2137 \\
7\end{array}$ & $\begin{array}{c}- \\
312,1\end{array}$ & $\mid-1197,7$ & $-355,0$ & $\begin{array}{c}3026, \\
3\end{array}$ \\
\hline 2000 & $-2504,6$ & $\begin{array}{c}1910 \\
3\end{array}$ & $\begin{array}{c}1710, \\
7\end{array}$ & $-901,6$ & $-170,4$ & $\begin{array}{c}2336, \\
8\end{array}$ \\
\hline Total net payments: & $-7173,9$ & $\begin{array}{r}1634 \\
7,0\end{array}$ & 1291, & $-4060,7$ & $-2375,9$ & $\begin{array}{c}19153 \\
, 5\end{array}$ \\
\hline
\end{tabular}




\begin{tabular}{||l|c|c|c|c|c|c||}
\hline & & & 0 & & & \\
\hline $\begin{array}{l}\text { Population in } \\
\text { median year 1997 } \\
\text { in 1000): }\end{array}$ & 58009 & 3661 & 5751 & 15611 & 8072 & 9946 \\
& & & 2 & & & \\
\hline $\begin{array}{l}\text { Total net payments } \\
\text { per capita (in Eur.): }\end{array}$ & $-123,67$ & $\begin{array}{c}4465, \\
17\end{array}$ & $\begin{array}{c}- \\
22,45\end{array}$ & $-260,12$ & $-294,33$ & 1925, \\
75
\end{tabular}

\begin{tabular}{|c|c|c|}
\hline & $\begin{array}{c}\text { Swede } \\
n\end{array}$ & Spain \\
\hline 1994 & 0,0 & $\begin{array}{c}3876 \\
7\end{array}$ \\
\hline 1995 & $-447,4$ & $\begin{array}{c}8005 \\
6\end{array}$ \\
\hline 1996 & $-384,2$ & $\begin{array}{c}6311 \\
2\end{array}$ \\
\hline 1997 & $-902,4$ & $\begin{array}{c}6041 \\
2\end{array}$ \\
\hline 1998 & $-570,9$ & $\begin{array}{c}7449 \\
2\end{array}$ \\
\hline 1999 & $-671,4$ & $\begin{array}{c}7758 \\
3\end{array}$ \\
\hline 2000 & $-827,0$ & $\begin{array}{c}5832 \\
9\end{array}$ \\
\hline Total net payments: & $-4437,0$ & $\begin{array}{c}45274 \\
, 9\end{array}$ \\
\hline $\begin{array}{l}\text { Population in } \\
\text { median year } 1997 \\
\text { (in 1000): }\end{array}$ & 8846 & 39323 \\
\hline $\begin{array}{l}\text { Total net payments } \\
\text { per capita (in Eur.): }\end{array}$ & $-501,58$ & $\begin{array}{c}1151 \\
36\end{array}$ \\
\hline
\end{tabular}

Notes: Trade figures of Belgium and Luxemburg are not available separately.

Total net contributions of Finland, Austria and Sweden are from 1995 to 2000. They have been inflated by 7/6 to make them comparable with those of the other Member States.

Source: Own calculations based on data of the European Commission and of the Statistical Yearbook of The Federal Republic of Germany. 


\section{Explaining Redistribution Through the Budget}

In this section we shall deepen our introductory remarks on the budgetary process given in section I. Following figure 1, we shall distinguish between for stages of budgetary decision making: a contractual stage and three post contractual stages I, II and III during which the distributive struggles take place. We predict that the (re)distributive outcome will be defined in the postconstitutional stages I and II according to the relative exit and non-entry opportunities of the member states and according to their size. Large member states with alternative options outside the EU will be in a stronger position to attract budgetary resources than large member states with fewer alternatives outside and small member states which were not so relevant for the survival of the Communitiy as a whole. This struggle will level off when in stage III interfirm ties have been established making threats of exit increasingly implausible. We predict roughly that, out of EU 15, France, the UK and Spain with its Southern allies will be in thew group of winners, while Germany and some smaller Member States will be in the losers' group.

\section{The Contractual Stage: The Treaty of Rome 1957}

The original purpose of the Union as laid down in the Treaty of 1957 was the establishment of a Common Market and not that of a system of redistribution among member states. In article 2 of the Treaty, redistribution is not even mentioned:

"The Community shall have its task by establishing a common market and by progressive approximation of economic policies, to promote throughout the Community a harmonious development of economic activities, a continuous and balanced expansion, a growing stability, the raising of the standard of living and closer relations among Member States." (Art. 2, 1957) ${ }^{3}$

Re-distributive elements show up only in later articles. Art. 40 para. 4 of the Treaty of $1957^{4}$ mentions the establishment of "agricultural guiding and guarantee funds" and Art. 123 the establishment of an "European Social Fund". The intention of these two funds was to achieve a fair distribution of the benefits generated through the Common Market. It seemed evident to fathers of the European Economic Community that industrialised and export oriented member states such as Germany would gain from free trade in the Common

\footnotetext{
${ }^{3}$ The original text of the Treaty of Rome is in German, French, Italian and Dutch. Translation by the authors.

${ }^{4}$ The new version of Art. 40 can be found in Art. 34 para. 4 of the Treaty of Amsterdam.

${ }^{5}$ The new version of Art. 123 can be found in Art. 146 of the Treaty of Amsterdam.
} 
Market, but that such gains were much less certain for the more domestically oriented economies such as Italy and France. Their governments feared that the rents of integration would be shifted out of their countries. Therefore they aimed at institutionalised claims on the rents which ought to be guaranteed through the Community budget. The Italian workers should be helped by the Social Fund to overcome their structural problems when transforming from an agrarian to an industrialised economy, and the French farmers should be subsidised through the agricultural guiding and guarantee funds. Note that market intervention through funds was a rational way for the Italian and French governments to preserve a claim on the rents of integration. Only through funds could they rely obtaining the desired share of the Common Market benefits. The higher the growth of intra-community trade of manufactured goods, the larger is the structural divergence to less adaptable markets such as labour and agriculture and the larger are therefore the budgetary transfers required to compensate the losers. Lump sum payments, in contrast, had to be negotiated anew in every year and were therefore not as reliable as funds. ${ }^{6}$

As funds were part of the Treaty, they were not unilaterally terminable and could only be removed by an unanimous decision. They became part of the acquis communautaire. Given that there is always at least one loser when a fund is abolished, it is difficult to see how unanimity could be achieved without replacing the fund by some other form of compensation, i.e. by perpetuating it. Therefore a persistent element of redistribution has been built in the European Economic Community since its beginning.

Critiques that funds are inefficient and should be abolished are therefore ill founded. It should rather be asked what alternative arrangements would have been at the disposal of the French and Italian governments in 1957 to secure permanently the rents of the Common Market. It would soon become clear that only arrangements which are framed in the constitutional Treaty were safe. That they generate inefficiencies and dead weight losses should not come up as a surprise for an economist.

The founding fathers of the European Union were not unaware of the expansionary potential built in these funds. As a precautionary (neither necessary nor sufficient) measure they split the budget in three separate branches: the administrative budget (covering the administrative expenditures of the Commission, the Council and the Court of Justice) the agricultural budget (representing the subsidies to farmers through the guiding and guarantee funds) and the social budget (for training and reintegrating workers subject to structural change). The tripartite budget allowed the members of the Council to

\footnotetext{
${ }^{6}$ An early emphasis of the compensation function of the EU budget has been given by Folkers (1995).
} 
continuously control spending and spending for whom. But control was not enough were decision making procedures turned out to be weak.

\section{Post-Contractual Stage I: France and the Financing of CAP 1958 - 1970}

Spending has developed quite differently in the three budgets during the early years of the Community from 1958 to 1970 . The administrative and the social budget have grown moderately, while the agricultural budget exploded (see figure 1). The reason can be found in the different rules of these funds.

The administrative budget and the social budget were financed by fixed share contributions as laid down in art. 200 of the Treaty (see table 2). To the administrative budget, the three large countries, Germany, France and Italy e.g. had to contribute 28 percent each. To the Social Fund or budget, France and Germany contributed 32 percent each while Italy contributed 20 percent. Changes were subject to unanimity. In the case of the social budget, regulations pertained also to the expenditure side. Subsidies were granted on a matching basis of 50 percent. Therefore benefits from the fund were not "free goods" for the member state governments. On the one hand the governments of the larger member states had to calculate the incremental costs of additional programs. On the other hand the smaller member state governments could not freely expand their programs because they needed the contributions and the consent of the larger member states. Under these constraints the size of the Social Fund remained quite small in this early period. It developed as designed in the Treaty requiring little post contractual decision making, hence confirming our hypothesis made in section I on contractual redistribution.

\section{Table 2: The Contribution Shares to the Administrative Expenditures and the Social Fund (1957-1970)}

\begin{tabular}{|l|l|l|}
\hline Member State & $\begin{array}{l}\text { Administrative } \\
\text { Expenditures }\end{array}$ & Social Fund \\
\hline Belgium & 7,9 & 8,8 \\
Germany & 28,0 & 32,0 \\
France & 28,0 & 32,0 \\
Italy & 28,0 & 20,0 \\
Luxembourg & 0,2 & 0,2 \\
Netherlands & 7,9 & 7,0 \\
\hline
\end{tabular}

Source: Treaty 1957 art. 200, see Peffekoven (1994, p. 44) 
The rules of the agricultural fund, in contrast, were quite different. First, the extent of the agricultural market was defined openly in Art. 38 par. 3 of the Treaty of $1957^{7}$. It was not exactly defined how many or which products had to be subsumed in the agricultural fund. Second, neither the system of price guarantees nor that of structural aid to farmers has provided for national cofinancing. Third, the contribution shares which each member state had to pay to the agricultural fund were not fixed in the Treaty. They were negotiated periodically in the Council.

The consequences confirm again our hypotheses made in section I: when contractual rules are incomplete, collective decisions have to be made at the post-contractual stage in the ongoing political process where the outcome depends on the decision rule to be applied there. As far as the budget is concerned, responsibility rested mainly with the Council which had to apply qualified majority rule according to art. 148 par. 2 of the Treaty of $1957^{8}$. But it has to be considered that qualified majority rule (as any non-unanimity rule) only works if the outvoted minority has to accept the result because it has nowhere to go; to say it differently, if its stakes in the Community are so large that it loses more from leaving the Community than from accepting its unbeloved decision. In these early years, however, the stakes the member states had in the Community were still small. Private contractual ties were not yet so developed. Therefore, an exit threat was credible and potentially harmful when made by a larger member state (see section I).

When we take these theoretical elements of contractual and post-contractual decision making together, we can understand why the agricultural budget developed so differently from the social budget and why its rules were capable of bringing the Community in its first deep crisis. Given the vagueness of the contractual rules, the French government wanted to extend the agricultural fund in a way that was disapproved by the other Member State governments. The French intentions were outvoted by the Council in Fall 1965. But given that the Community was so young and the stakes in it were still small, the French government, under President de Gaulle, had the option to exit and to jeopardise the Community's future. In Fall 1965 the French government chose to boycott all further meetings of the Council until the unanimity rule was formally resumed in the so-called Luxembourg compromise of January 29, 1966. What we can learn is that the unanimity rule crowds out qualified majority rule in the case of a credible exit threat.

Table 3 illustrates how much bargaining must have taken place in the process of agricultural budget determination in the early sixties. Five different distributions

\footnotetext{
${ }^{7}$ The new version of Art. 38 par. 3 can be found in Art. 32 par. 3 of the Treaty of Amsterdam.

${ }^{8}$ The new version of Art. 148 par. 2 can be found in Art. 205 par. 2 of the Treaty of Amsterdam.
} 
of country contribution shares have been recorded since the common agricultural fund has been introduced in 1962. Moreover, these shares were only the basic units on which further increments or decrements have been negotiated from year to year. The outcome was fundamentally different from the policy in the Social Fund whose volume remained negligible throughout this early period.

\section{Table 3: Contribution Shares to the Agricultural Fund 1962-1970}

\begin{tabular}{|l|l|l|l|l|l|}
\hline $\begin{array}{l}\text { Member } \\
\text { State }\end{array}$ & $7 / 1962$ & $1965 / 66$ & $1966 / 67$ & $7 / 1967-$ & 1970 \\
$12 / 1969^{\mathrm{b}}$ & \\
\hline Belgium & 7,90 & 7,95 & 7,95 & 8,10 & 8,25 \\
Germany & 28,0 & 31,67 & 30,83 & 31,20 & 31,70 \\
France & 28,0 & 32,58 & 29,26 & 32,00 & 28,00 \\
Italy & 28,0 & 18,00 & 22,00 & 20,30 & 21,50 \\
Luxembour & 0,20 & 0,22 & 0,22 & 0,20 & 0,20 \\
g & 7,90 & 9,58 & 9,74 & 10,35 & 10,35 \\
Netherlands & & & & & \\
\hline
\end{tabular}

${ }^{a}$ Fixed shares only. Variable supplementary shares (according to a Member State's net imports of particular farm products) are not included.

${ }^{\mathrm{b}}$ Only for guiding expenditures; for guaranty contributions so far as not covered by customs revenues (which were transferred to 90 percent to the Community)

To summarise: The examples of the Social Fund and the Agricultural Fund show the relevance of strict versus weak contractual budget rules. In the case of the Social Fund, post-contractual collective decision making has been avoided because its size has already been delineated in the Treaty. In the case of the Agricultural Fund, however, collective decision making has been shifted from the contractual to the post-contractual stage where collective decisions were taken under the French government's threat to leave the Community and to jeopardise its further existence. The budgetary consequences can be seen in the steep increase of agricultural spending in figure 2 after 1965. Indeed, the Luxembourg compromise prevailed in the Council for the next 20 years.

\section{Post-Contractual Stage II: Britain and Spain/Portugal/Greece 1971 - 1986}

Threats of exit determined budget decisions also in the following period of the history of the Community from 1971 to 1986 . Now, the question was about the UK rebate on the contributions to the budget. The origin of this dispute rested 
mainly in the decision on Community's own resources of $1970 .{ }^{9}$ The tripartite budget with earmarked contributions had been given up in favour of a unitary budget financed initially by two sources of revenues: revenues of customs and other levies and a contribution by member states calculated on their respective standardised VAT base. Later on, these two resources have become known under the names of "traditional own resources" and "VAT own resources". Formally the decision on Community's own resources had the quality of a change in the Treaty which remained valid until it is replaced by a new decision on the Community's own resources. Thus, the status quo could only be changed by unanimity (Lienemeyer 2002, pp. 205-214). We shall return to the consequences of this rule in subsection 4.

The expected political advantage of the unitary budget was that it allowed the separation of the revenue side from the expenditure side of the budget and so eliminated an open discussion on the distribution of the burden of the Common Agricultural Policy (CAP). Moreover, it allowed the development of the new system of structural funds out of the existing Social Fund and the Guidance Department of the Agricultural Fund without the need to respect the former percentage contributions (see table 2 above).

The expectation that looser rules on the expenditure side and rate base payments on the revenue side facilitated the discussion on the distribution of the financial burden was, however, not fulfilled. When the United Kingdom joined the Union in 1973, it was supposed to accept the system of Community's own resources of 1970 as an acquis communautaire. It had not only to waive all its customs revenues to the Community, but also to contribute to the VAT own resources. Given that British agricultural imports were large and own (subsidised) agricultural production relatively small, compared to those of other member states, the overall balance resulted in a large net transfer in favour of the Community which was unacceptable for the British tax payers and their government (see table 4). While this problem could have been negotiated relatively easily under the previous system of earmarked budgets with country specific contribution shares, it became a question of allocating benefits and costs of a common pool under a unitary budget in which quid pro quo was eliminated. Under the threat that the British citizens would vote against EC membership and the United Kingdom would leave the Community, the Council granted several yearly rebates and repayments up to 1984 when a permanent rebate was conceded in the own resources decision of the Council and the member states. ${ }^{10}$

\footnotetext{
${ }^{9}$ Beschluss 70/243 des Rates vom 21. April 1970 über die Ersetzung der Finanzbeiträge der Mitgliedstaaten durch eigene Mittel der Gemeinschaft.

${ }^{10}$ It has to be added that the establishment of the structural funds had also the specific purpose to increase British receipts in order to reduce the British net payer position.
} 


\section{Table 4: Net Receipts from the EU Budget 1981 - 1984 in million ECU (excluding public good benefits)}

\begin{tabular}{|l|l|l|l|l|l|}
\hline $\begin{array}{l}\text { Member } \\
\text { State }\end{array}$ & 1981 & 1982 & 1983 & 1984 & $\Sigma 1981-84$ \\
\hline Belgium & 320 & 310 & 210 & 330 & 1170 \\
Denmark & 280 & 280 & 330 & 500 & 1390 \\
Germany & -1770 & -2320 & -2300 & -2950 & -9340 \\
Greece & 160 & 690 & 940 & 990 & 2780 \\
France & 540 & 0 & 10 & 330 & 220 \\
Ireland & 590 & 740 & 770 & 920 & 3020 \\
Italy & 780 & 1520 & 1320 & 1710 & 5330 \\
Luxembour & 270 & 250 & 270 & 280 & 1070 \\
g & 220 & 350 & 370 & 510 & 1450 \\
Netherlands & -1380 & -1820 & -1910 & -1950 & -7060 \\
United & & & & & \\
Kingdom & & & & & \\
\hline
\end{tabular}

Source: Messal (1991, p. 113) and own calculations

Threat rather than formal decision making rules also determined the concessions made to the coalition of the Spanish, Portuguese and Greek governments at the time of their accession in 1984/85 and even more later on when the Single Market was at stake in 1986. In the early eighties, it was not implausible to assume that these nations might fall back into popular socialism or communism. Hence, their alternatives outside had to be estimated as relatively tempting compared to membership. The EC member states, on the other hand, might have felt uneasy with communist neighbours in the East as well as in the South. Therefore, one can understand that they were willing to pay a price for the accession and adherence of these countries. ${ }^{11}$ In fact, real spending on structural funds has doubled in the eighties (see figure 2).

To sum up: The concessions made to France and to Spain and its allies on the expenditure side and to the United Kingdom on the revenue side make clear that, on important issues, it is not so much the formal decision rules as laid down in the Treaty, but rather governments' capacity to credibly threaten to harm the Community by terminating membership that is important. Not all member states, however, were able to exert such threats. Germany e.g. had no credible alternative to its membership in the Community. Though its net payments were at least as large as those which the United Kingdom was expected to make, it was unable to exert threat. For nobody seriously thought that Germany was able to

\footnotetext{
${ }^{11}$ For Greece, it was the problem of adherence as it entered in 1981 already.
} 
leave the Community. Geographically enclosed between France and the COMECON it had nowhere to go. It turned out that the German government had even to contribute to filling the gap left back by the British rebate which further increased its net payer position. Similarly, while some smaller Member States such as the BENELUX, Austria and Sweden could threaten to stay outside, the other Member States would not be concerned too much. They were too small for their withdrawal to endanger the survival of the Community so that their threat would not be effective as a bargaining tool for attracting budgetary resources. Indeed, all of them except Belgium remained net payers. Considering France, Spain and its allies, the United Kingdom and Germany together, it can be seen that their net receiver or net payer positions depended not only on the common rules as laid down in the own resources decision, but to a large extent also on their relative exit options.

\section{Post-Contractual Stage III: The Budget Under Quali- fied Majority/Unanimity Rule 1987-2003}

In the following years, the power of governments to enforce budget decisions by threat of exit ${ }^{12}$ decreased continuously. Member states grew closer together. Firms made cross border investments. A network of ties emerged making threats of exit increasingly less convincing. ${ }^{13}$

As it has become evident that member states would firmly adhere to the Community, it became possible to depart from the Luxembourg Compromise of 1966 and to return gradually to the collective decision rules of Art. 148 par. 2 of the Treaty of Rome. ${ }^{14}$ A first step was the Single European Act of 1987 where qualified majority rule was extended to the issues of the Single Market. A second step was the compromise of Ioannina of 1994 where qualified majority was maintained (even with Austria, Finland and Sweden as new members), but the minority required for blocking an issue (temporarily) was set at 23 votes (26 percent) instead of 25 votes ( 29 percent) out of 87 votes. The actual end point of this development is the Treaty of Amsterdam which allows qualified majorities for Council decisions in much more fields than before.

The return to qualified majority rule after Amsterdam had only minor effects on the expenditure side of the budget (see table 5). Net receivers have a comfortable blocking minority of 32 votes in the Council, strong enough to maintain the status quo of the allocation of Union's budgetary resources on agriculture and structural funds. The net payers are in a minority position too.

\footnotetext{
${ }^{12}$ Or: threat of non-entry in the case of Spain.

${ }^{13}$ Vaubel (2001, pp. 108-115) argues that EU politicians and public officials often form a sort of inner circle of friendship, artificial harmony and logrolling at the costs of the public at large. Therefore one can expect that the inner ties promote coherence too.

${ }^{14}$ The new version of Art. 148 par. 2 can be found in Art. 205 par. 2 of the Treaty of Amsterdam.
} 
They achieve 35 votes only. Two Member States, France and Italy, break even with 10 votes each. ${ }^{15}$ Even a proposal to reallocate some of the redistributive funds to provide public goods is unlikely to be accepted by the blocking minority of actual net receivers. For the costs of reduced transfers are very likely to be borne by them while the benefits accrue typically to all member states.

\section{Table 5: Net Receipts per Capita (1994-2000) and Voting Power (1995)}

\begin{tabular}{|c|c|c|c|c|}
\hline & $\begin{array}{l}\text { Net position } \\
\text { (receipts - } \\
\text { contri-butions } \\
\text { per cap.) EUR }\end{array}$ & $\begin{array}{l}\text { Votes in } \\
\text { Council abs. }\end{array}$ & $\begin{array}{l}\text { Shapely } \\
\text { weight percent }\end{array}$ & $\begin{array}{l}\text { Population } \\
\text { share percent }\end{array}$ \\
\hline Austria & -294 & 4 & 4,5 & 2,2 \\
\hline Belgium & $\begin{array}{l}346 \\
\text { Lux.) }\end{array}$ & 5 & 5,5 & 2,7 \\
\hline Denmark & 517 & 3 & 3,5 & 1,4 \\
\hline Finland & 128 & 3 & 3,5 & 1,4 \\
\hline France & -9 & 10 & 11,7 & 15,7 \\
\hline Germany & -744 & 10 & 11,7 & 22,0 \\
\hline Greece & 2801 & 5 & 5,5 & 2,8 \\
\hline Ireland & 4465 & 3 & 3,5 & 1,0 \\
\hline Italy & -22 & 10 & 11,7 & 15,4 \\
\hline Luxembourg & 346 (incl. B.) & 2 & 2.1 & 0,2 \\
\hline Netherlands & -260 & 5 & 5,5 & 4,2 \\
\hline Portugal & 1926 & 5 & 5,5 & 2,6 \\
\hline Spain & 1151 & 8 & 9,6 & 10,5 \\
\hline Sweden & -501 & 4 & 4,5 & 2,4 \\
\hline $\begin{array}{l}\text { United } \\
\text { Kingdom }\end{array}$ & -124 & 10 & 11,7 & 15,8 \\
\hline $\begin{array}{l}\text { Qualified } \\
\text { majority }\end{array}$ & & 62 & & \\
\hline $\begin{array}{l}\text { Blocking } \\
\text { minority }\end{array}$ & & 25 & & \\
\hline Total & .. & 87 & 100 & 100 \\
\hline
\end{tabular}

Remarks: The data of Austria, Finland and Sweden were adjusted for 7 years of membership.

Source: Own calculations (see table 1) and Wissenschaftlicher Beirat beim Bundesministerium für Wirtschaft und Technologie (1999).

\footnotetext{
${ }^{15}$ Strictly speaking: Their net contributions were 9 and 22 Euro respectively per capita over a seven years' total, i.e. 1 to 3 Euros per capita per year, close enough to no net contribution (see table 1).
} 
On the revenue side the principle of a status quo oriented unanimity has been maintained since the first decision on own resources of $1970 .{ }^{16}$ Hence an existing decision can be replaced only by a new unanimous decision (Art. 269 [ex 201] of the Treaty and III.2 above). This principle has important consequences for the net budget incidence. When the incidence of expenditures drifts away from the incidence of revenues (for the reasons given above) and net payers positions are built up, then there is no way for the net payers to get rid of their burden. They will neither be able to reduce the general contribution rates nor to shift their own burden on the shoulders of the net receivers. Both attempts will fail to be accepted by the latter. There is only one way for the net payers to protect their interests: to veto proposals coming from the net receivers to further increase their contributions to the Union's own resources. Such a veto is indeed the only way for net payers to protect themselves against ever growing demands of net receivers. Any promises to net payers that higher contributions which they would make would be used for providing Union wide public goods should not be taken seriously. For under general fund financing it is upon net receivers to channel these funds towards themselves.

To summarise: Decision making on the EU budget has resulted in a redistributive deadlock. Net receivers use their blocking power to object to any reallocation of resources away from their narrow own interests, and net payers, anticipating net receivers' power to attract the additional resources to themselves, will veto any increase in their burden. But net payers cannot enforce a decrease of their burden; for that would be objected by net receivers under unanimity rule. Therefore the status quo is a stable equilibrium. Preserving the status quo means that the net budget incidence as it came out of the power play in the post contractual stages I and II will be preserved. Tabellini's claim that more public goods should be provided will remain politically unnoticed.

It is important so see the effect of the status quo related unanimity rule for decisions on Union's own resources. Had the net payers the possibility to unilaterally terminate an existing own resources decision, all Member State governments would be under pressure to discuss budget revenues and expenditures de novo and as a whole. The separation of revenues from expenditures would be abolished, and substantial reforms might become possible. Though such a change might be desirable, it is irrelevant for our discussion; for no unanimity would be found to support it. Therefore it is unlikely that the EU budget process can be reformed within its own rules.

An example may illustrate how sensitively governments often react on proposals to change the distribution of the burden. When, in anticipation of the Berlin

${ }^{16}$ 70/243/EGKS, EWG, Euratom, Abl., Nr. L 94 (1970), p. 19. 
summit of 1999, the German government made some exploratory calculations on the possibility of obtaining an UK type rebate on its contributions, the Spanish government promptly reacted by submitting a counter-proposal requiring that member states' contribution rates should rise progressively with respect to GNP with the obvious effect that the German government should pay more instead of less to Union's own resources. ${ }^{17}$ The Spanish proposal was not even mentioned at the summit, but it had the effect of taking the German proposal off the agenda, and the status quo was maintained.

If these deliberations are correct, the likely result is effectively one of nondecision making. The budget is likely to grow in line with the built-in rules. These rules are mainly defined by the ceiling of 1,27 percent of Union's GDP as assessed in the own resources decision of 1992. The ceiling has been renewed in 1995 and in 1999, and it will remain at this level until 2006 when it may be prolonged again. Some readers may not be too unhappy with the deadlock because it guarantees a sort of "second best": As long as it is apparently not feasible to provide (more) Union wide public goods, they may say, it is fortunate that the budget has a built in stabilizer holding further growth down at the rate of growth of Union GNP.

A critical review of the assumptions made: First of all, one may object that it is a simplification to focus only on the Council as a decision maker. Indeed, there are further players such as the Commission which has to make mid-term projections and which has to prepare the yearly budget. Moreover, negotiations take place between the Commission and the Council. But within the Council ministers have to fight fiercely for their national interests as contributors and receivers of funds. The better they fight, the larger is the support they will receive from their voters at home. And after all, they have to survive in national elections. It may be criticised, moreover, that the European Parliament has not been taken explicitly into account. We justify the omission with the fact that the European Parliament has no right of initiative. It has only the right to decline or to change a budget proposal made by the Council in the field of non obligatory expenditures or to reject the budget as a whole. But too much dissent between the Council and the Parliament should not be expected. For the national representatives, too, have an incentive to fight primarily for their national interests, i.e. for the interests of their voters at home.

\section{Decision Making in the Future Years}

What will be the outcome of the budgetary process in the future? In order to make a prediction one has to separate two factors which may have a major

\footnotetext{
${ }^{17}$ See H. Bünder, Die mühsame Suche nach dem richtigen Reformmodell, Franfurter Allgemeine Zeitung Nr. 193, 21 August 1998, p. 12.
} 
impact on the budgetary process: (1) Enlargement of the European Union to up to 27 member states, (2) Constitutional Changes proposed by the Convention and adopted by member states in a new European Constitution.

\subsection{The Impact of Enlargement of the European Union}

Predictions on the impact of enlargement of the European Union are difficult and have therefore to rely on strong assumptions. We believe that the mechanisms of exit threat of the post constitutional stages I and II will not reemerge. The Union has become large enough to bear the exit of some of the new accession states. Therefore accession states lack a threat potential comparable to that of France in the sixties or the UK and Spain in the seventies and eighties. A good sign of this development is that the right of exit is likely to be granted explicitly in the new European Constitution. ${ }^{18}$ Therefore it can be expected that collective decisions will be made according to the rules written in the Constitution. Table 6 shows the voting power of the traditional net receivers, of the traditional break even countries and of the traditional net payers plus the voting power of the accession countries all weighted with the distribution of votes as decided at the summit of Nizza in 2000. Accession states have been taken together because roughly all of them are likely to become net receivers. ${ }^{19}$ With 108 votes in the Council they can form a blocking minority allowing them to obtain at least a part of the revenues which previously went to the traditional net receivers. The non discrimination constraints on CAP and the structural funds are unlikely to be changed. As a consequence, some of the actual break even and net receiver states will become net payer states. Net payers' voting power will, however, not rise so much as to achieve qualified majority. Adding their votes to those of the budgetary break even countries will increase total votes of (net) payers from 95 to 153 which is still far away from the required qualified majority of 254 votes. Even if some more member states governments would become net payers and join their coalition, voting power would not change substantially. Therefore the net receivers will be able to maintain the size of the agricultural and of the structural funds and to suppress public good programs. On the other hand net payers can use their voting power to block further expansion of the budget. All in all, therefore, little change has to be expected. Only the strain on the resources of the budget is likely to increase.

\footnotetext{
${ }^{18}$ Art. 46 of the Preliminary Draft of October 28, 2002.

${ }^{19}$ Malta, Slovenia, Czech Republic and Cyprus will receive an extra payment avoiding them to be pushed into a net payer position.
} 


\section{Table 6: Status quo Distribution of Voting Power in the Council after Eastern Accession}

\begin{tabular}{|l|c|c|}
\hline $\begin{array}{l}\text { Groups of Member } \\
\text { States }\end{array}$ & Number of votes & $\begin{array}{l}\text { Number of votes in } \\
\text { percent }\end{array}$ \\
\hline $\begin{array}{l}\text { Net receiver states 1994- } \\
2000\end{array}$ & 84 & 24,4 \\
\hline Accession states & 108 & 31,3 \\
\hline $\begin{array}{l}\text { Break even states 1994- } \\
2000 \text { (F \& I) }\end{array}$ & 58 & 16,8 \\
\hline $\begin{array}{l}\text { Net payer states 1994- } \\
2000\end{array}$ & 95 & 27,5 \\
\hline Blocking minority & 91 & 26,4 \\
\hline Qualified majority & 254 & 73,6 \\
\hline Total & 345 & 100,0 \\
\hline
\end{tabular}

Source: Own calculation, see Table 5.

\subsection{The Impact of constitutional changes}

A change of the budget policy may, however, arise when the budget balancing constraint is dropped (art. 269 ex 201 of the Treaty of Amsterdam). A potential leakage of this constraint comes from the European Investment Bank (art. 267 ex 198 e of the Treaty of Amsterdam) which is supposed to provide loans and securities to governments and firms in structurally backward regions and industries. It is tempting for politicians to soften the budget constraint through this back door especially under fiscal strain as it is to be expected after Eastern accession (Blankart 1996).

A more dramatic change may result from the discussion in the Convention. The intention is to divide the European Constitution in two parts: a constitutional part where changes are subject to unanimity and policy part where decisions can be made by qualified majority rule. Up to now, it is not yet clear whether the revenue side will remain in the constitutional part. There are also strong pressures to put it into the policy part and to subject it to a qualified majority. Then it would be likely that a qualified majority of net receivers would dictate larger contributions and increases in the volume of the budget. But it is unlikely that these additional means would be spent for public goods and not for redistribution given the large number of net receivers. ${ }^{20}$ Therefore such a

\footnotetext{
${ }^{20}$ If all accessing states are net receivers they will form a blocking minority of 101 votes in the Coucil. They can prevent a qualified majority of 258 out of 345 votes.
} 
decision seems unlikely. ${ }^{21}$ But one can never know what bundles of decisions packed in Pandora's box will be generated in the discussions of the Convention.

\section{A Way out of the Deadlock}

In this section we assume that Pandora's box will remain locked for the foreseable future, i.e. in particular that the unanimity rule on the revenue side and the qualified majority rule on the expenditure side will be maintained. Hence the deadlock as well as budget ceilings will be prolonged. There will be neither a substanial provision of public goods nor a budget explosion and hence the budgetary deadlock will remain. For this case, we want to discuss the solution of a separate supplementary budget, which could be suited to overcome the deadlock and to allow the provision of Union wide public goods if desired.

In order to be able to discuss various proposals in a realistic framework, we want first to present three conditions which, in our eyes, are necessary prerequisites for any consensual agreement of member states on the budgetary issue:

a. Separation: collective decision making on public goods cannot take place within the existing budgetary rules. Net receivers would channel the means into redistribution and, in anticipation of net receivers' behaviour, net payers would refuse to contribute. Therefore, a new, separate budget: "The public good budget" has to be introduced. But the old budget: "The general budget" has not to be given up in order to avoid that there are losers. ${ }^{22} 23$

b. Veto: the new budget procedure must be designed in a way that no party risks ending up in net payer position or aggravating its existing net payer position. Thus some veto-element must be part of the new solution.

c. Contributions: since willingness to pay for public goods depends on a number of factors such as the characteristics of the good such as individual preferences, income, price etc., the rules of financing

\footnotetext{
${ }^{21}$ Indeed, no consensus could be found on this issue by the working group of the Convention in charge by March 2003.

${ }^{22} \mathrm{We}$ acknowledge that new rules are required. But we doubt that theses rules can be adopted without an integration of the status quo. Insofar our proposal differs from those e.g. by Buchanan and Lee (1994).

${ }^{23}$ Some may object that the principle of the unity of the budget is violated. But it has to be remembered that the Union never had a fully integrated budget. The budget of the European Community of Coal and Steel (during its existence) as well as the budget on loans and credits has always been separated from the general budget (see Strasser 1991, pp. 46-49).
} 
should be flexible. They should take the form of contributions rather than rate base payments.

All in all, we are searching for a pareto-superior procedure. Leaving inefficiencies of the existing system aside, we want to find a procedure that opens opportunities for the provision of public goods available in the Union on a consensual basis. Insofar, our proposal is purely positive. It can be taken up by any party that wants to gain votes. It differs from normative proposals targeted to a change of the existing rules implying winners and losers and hence opposition.

\section{Wicksellian Unanimity}

The strongest form of decision making under veto is the use of the Wicksellian unanimity rule. All voters have a veto right and so no participant will end up in a position of being exploited. Moreover no vote weighting is necessary as under the actual qualified majority rule. A major disadvantage is, however, that vetoes have no price to the voters. They can just say no and expect that someone else will take the burden of creating a new proposal. Therefore Wicksellian unanimity is a heavy process not suitable for the European Parliament. Even in the Council, unanimity seems to be practicable only when restricted for important decisions.

A way to make unanimity rule more flexible is to allow unilateral termination of the existing arrangement after a certain period, say five years, by one or more parties. If no termination is requested, the arrangement will be prolonged for another five years etc. Unilateral termination after the agreed upon period puts the other members under pressure to find a new arrangement, to test whether the whole enterprise is still worth its costs and to ensure that no member will be exploited in the long run. A member state may become net payer for some years, but not for an indefinite period of time. A disadvantage is, however, that a new arrangement, though basically beneficial, may not be found because of excessive negotiation costs. Then, the community of states might fall back into a precontractual stage. Such a disadvantage can be avoided by voting by veto.

\section{Voting by Veto}

Under voting by veto as developed by Dennis Mueller (Mueller, 1989), each of $\mathrm{N}$ participants submits a proposal on the size and the cost sharing of a public 
good to be provided. The status quo is added as a further proposal. Each participant has the right to eliminate - to veto - one proposal. Therefore she has an opportunity to compare and to evaluate the relative advantages of different proposals one of which she can veto. A veto has a cost. For only those who make a proposal have the right to veto. Who may choose first, second etc. is determined by lottery. Eventually, one proposal remains as the proposal which has not been vetoed and which is therefore acceptable by all participants.

Each person has an incentive to take account of other participants' preferences when making a proposal in order to avoid its elimination. Since many alternatives are proposed and subject to a veto, there is more search and better solutions will come about. Every participant can protect herself from being exploited to by vetoing the least desired proposal. So do all other persons, and the resulting proposal will be fair and efficient. ${ }^{24}$

A further advantage of voting by veto is that it produces no cycling because the procedure has a finite number of steps. For a given set of rankings and sequence of veto-voting, it produces a unique outcome (Mueller 1984). It is true that it may yield

different winner for the same set of rankings under a different order of vetovoting. But it has to be considered that the procedure produces incentives to select proposals with respect to other voters' preferences, i.e. proposals benefitting not only the particular, but all voters.

Among the possible disadvantages, three are worth to be mentionned:

First: the procedure is often said to be unfair because it does not differentiate between large and small member states. All have the same voting power. Such an argument is, however, misleading. For the same would hold under unanimity rule. Or even with the qualified majority rule, a group of small member states hold a veto position. The advantage of the voting by veto-concept is its inherent reciprocity. Any small member state is well advised submitting proposals which take into account the interests of large member states, because otherwise such proposals will be automatically vetoed by one of the large member states. The voting by veto-concept thus does not provide undue influence of small member states but rather mitigates the power of large and small member states reciprocally.

Second: voting by veto is said to be complicated. This is, however not the case. The only additional work which is required compared to usual voting is that each voter establishes a ranking of the alternatives turned in. The elimination

\footnotetext{
${ }^{24}$ See Mueller (1989, pp. 139-145 as well as Mueller 1984).
} 
procedure will be made by a computer which will deliver the result within a minute.

Third, the number of participants may be relevant for the outcome. In a small number setting, participants may behave strategically, in a large number setting, an individual may lack of the incentive to participate actively in the voting process. These are two well known characteristics of all voting systems. In so far voting by veto is not different. But it has to be considered that voting by veto is applied at a specific institution: the Council which is neither very small nor very large. It will have 27 members after full accession or 28 when Turkey joins. Compared to competition policy, a market with that many suppliers would be regarded as fairly competitive. Therefore neither the problem of too few or too many is likely to be prevalent.

What has been said for strategic behavior and active participation in voting also holds to some extent for collusion. With as much as 27 or 28 participants it is not easy to maintain voting discipline among colluders. Nevertheless one may argue that, differently from markets, collusion in politics is visible and can be checked easily. Moreover it is not prohibited by law. In order to be on the safe side, we have developed a voting scheme through which colluders are punished. We propose to give the victims of collusion an extra veto.

In mind we have the type of collusion in which all of the net receivers of the general budget (see above V.a) submit identical proposals for the public good budget all exploiting net payers, and the number of vetoes by the latter is not large enough to cancel out the number of net receivers' proposals. The procedure of voting by veto boils down to simple majority voting where the number of votes count. Such an outcome could be prevented by giving all net payers of the general budget a net payers' veto. This is an a priori veto right, allowing them to eliminate all proposals which increase their net payer position. ${ }^{25}$ The remaining proposals would be eliminated by lot according to the voting by veto procedure until only one proposal remains. The procedure may imply on the one hand that not all member states may be able to vote. Which ones is determined by the above lot procedure. On the other hand, net receivers will anticipate that their common exploitative proposals will be eliminated inducing them not to turn them in in the first place. Hence all proposals turned in will be non-exploitative, and all participants will be able to submit a veto.

Given the number of participants, we have, however, good reasons to assume that a net payers' veto is not necessary as seen from the actual perspective. We therefore propose to start with the basic model of voting by veto, to collect and

\footnotetext{
${ }^{25}$ The proposal of a veto right for net payers has originally been proposed by the European Constitutional Group (1993).
} 
to amend the proposal later on by a net payers' veto if collusion should really become a problem.

\section{Implementation of Voting by Veto in the Treaty}

The following wording is being proposed which has to be integrated into the title on financial provisions. In Art. 269 EC a third paragraph should read as follows:

"Additional to the general budget under the provisions of the preceding paragraphs of this article there will be a second budget on expenditures for public goods to be provided by the European Union. For this budget the following procedural rules are binding: Each year every Member State has to submit to the Council a draft law for a regulation for the raising of revenues and the regulation of expenditures for the Union's public goods budget according to the regulations issued by the Commission. ${ }^{26}$ One draft law is last year's public goods budget. Member States have to exercise sequentially their right to eliminate one draft law each. Which Member State votes first, second and so on is determined by lot. The process stops when there is only one draft law left. This draft law which is not vetoed shall be adopted and put into effect by the Council."

\section{Conclusions}

In our approach explaining the EU budget, politicians pursue policies promoting their re-election at home. On the expenditure side of the budget, they try to maximise the flow of resources towards their electorate, and on the revenue side they want to minimise their contributions to the budget. Both goals can be pursued simultaneously because the two sides of the budget are institutionally separated. A combined evaluation of costs and benefits does not take place. Any attempt of net payers and net receivers to link, at least, partially revenues to expenditures will be in vain. For under the principle of general fund financing such earmarking is not enforceable. Therefore the budget ends in a deadlock.

\footnotetext{
${ }^{26}$ The Commission may require to split the public good budget into different parts of contributions and expenditures in order to apply voting by veto on different public goods.
} 
Some authors plead for linking the two sides of the budget by giving the European Union the power to tax and by making the European Parliament responsible for levying the taxes. President Romano Prodi has supported reforms in such directions at the opening session of the European Convention (Prodi 2002). In the Commission it is expected that such a system would strengthen representatives' responsibility before the voters and simultaneously end the disdained discussion on which member state is net payer and which is net receiver (Goulard and Nava of the European Commission in a personal statement, 2002). ${ }^{27}$

We do not believe that members of the European Parliament would behave less egoistically in spending than ministers in the Council. After all, members of the European Parliament also depend on their voting base at home. The more money they bring home, the more votes they will receive, and indeed there is little hope of reaching a unanimous decision to abolish the common EU policies on which this spending takes place. EU policies are part of the Treaty and can only be replaced by unanimity of the member states. ${ }^{28}$

A difference has, however, to be expected on the revenue side. When the European Parliament is given the power to tax, it will be able to increase taxes by less than unanimity. Under such a parliamentary regime tax increases will be much easier to enforce than under the present system of own resources which requires unanimity of the member states for increasing contributions and hence taxes. Moreover it has to be expected that with a second and - with Turkey - a third round of accession, the income distribution in the Union will become increasingly skewed to the left making redistribution increasingly attractive for a majority of voters and their representatives in the European Parliament.

In summary, giving the responsibility for taxing and spending to a majoritarian European Parliament is likely to lead to a higher budget with more redistribution. The provision of Union wide public goods, by contrast, will not be promoted by such a change. The provision public goods in the Union does not require majority voting, but cooperation. And cooperation requires trust which can only be achieved in a procedure preventing one partner finding herself or himself in a position of being exploited. Our proposal for promoting both, trust and cooperation, is to allow voting by veto in the Treaty.

\footnotetext{
${ }^{27}$ We shall not discuss the numerous alternative reform proposals made in recent years. For a summary see Heinemann (1998).

${ }^{28}$ One way to reduce the incentives of the representatives to maximize transfers to their home constituency and to pursue more Union wide goals is to merge all of Europe into one electoral district. The pros and cons are discussed in Blankart and Mueller (2004).
} 


\section{References}

Baldwin R.E., François J.F. and Portes R. (1997), The costs and benefits of eastern enlargement: the impact on EU and central Europe, Economic Policy, 24 (April): 127-176.

Blankart. Ch. B. (1996), The European Union's Debt Question: A Conceptional Viewpoint, Constitutional Political Economy, 7: 257-265.

Blankart, C.B. and Mueller, D.C. (2004), Towards a More Consistent Design of Parliamentary Democracy and Its Consequences for the European Union (forthcoming).

Brennan, G. and Buchanan, J.M. (1985), The Reason of Rules. Constitutional Political Economy, Cambridge (Cambridge University Press).

Buchanan, J.M. (1975), The Limits of Liberty: Between Anarchy and Leviathan, Chicago: University of chicago Press.

Buchanan, J.M. and Lee, D.R. (1994), On a Fiscal Constitution for the European Union, Journal des économistes et des études humaines, 5 (Nr. 2-3): 219-232.

EU Commission (2001), Aufteilung der operativen EU-Ausgaben 2000 nach Mitgliedstaaten, Brussels.

Europäische Kommission (1995), Die Finanzverfassung der Europäischen Union, Luxemburg.

European Constitutional Group (1993), A Proposal for a European Constitution, London, www.European-Constitutional-Group.org

Folkers, C. (1995), Welches Finanzausgleichssystem braucht Europa? In: Karl, H. (Ed.), Regionalentwicklung im Prozess der Europäischen Integration, Bonn: Europa-Union-Verlag, pp. 87-108.

Goulard, S. and Nava M. (2002), A more democratic system for financing the EU budget: a challenge for the European Convention, manuscr., Brussels (European Commission).

Heinemann, F. (1998), EU Finanzreform 1999. Eine Synopse der politischen und wissenschaftlichen Diskussion und eine neue Reformkonzeption, Gütersloh: Verlag Bertelsmann Stiftung. 
Hosli, M.O. (1996) Coalitions and Power: Effects of Qualified Majority Voting in the Council of the European Union, Journal of Common Market Studies, 34 (No. 2, June): 255-273.

Lienemeyer, M. (2002), Die Finanzverfassung der Europäischen Union, BadenBaden: Nomos.

Messal, R. (1989), EG-Finanzierung und Lastenverteilung - Die Reform des EG-Finanzierungssystems 1988 - Bonn: Stollfuss Verlag.

Messal, R. (1991), Das Eigenmittelsystem der Europäischen Gemeinschaft, Baden-Baden: Nomos.

Messal R. and Klein, A. (1993), Finanzlasten und Eigenmittelstruktur der europäischen Gemeinschaft, Wirtschaftsdienst 73 (No. 7): 375-383.

Milbrandt, B. (2001), Die Finanzierung der Europäischen Union. Perspektiven für eine Osterweiterung, Baden-Baden: Nomos.

Mueller, D.C. (1984), Voting by Veto and Majority Rule, in: Hanusch, H. (Ed.): Public Finance and the Quest for Efficiency, Detroit Mich. (Wayne State University Press), pp 69-86.

Mueller, D.C. (1989), Public Choice II, Cambridge (Cambridge University Press).

Peters, T. (1996), Reform der EU-Abstimmungsverfahren, in: Streit, M.E. and Voigt, S. (Eds.): Europa reformieren: Ökonomen und Juristen zur zukünftigen Verfasstheit Europas, Baden-Baden: Nomos, pp. 85-97.

Peffekoven, R. (1994), Die Finanzen der Europäischen Union, Mannheim: Bibliographisches Insitut und Brockhaus AG.

Prodi, R. (2002), Speech at the opening session of the Convention for the future of Europe, Brussels, February 28.

Raunio, T. and Wiberg, M. (1998), Winners and Losers in the Council: Voting Power Consequences of EU Enlargements, Journal of Common Market Studies, 36 (Nr. 4): 549-562.

Stegarescu, D. (2001), Zahlmeister und Nutzniesser der EU - Die Nettozahlungsposition als Vergleichsmasstab, Manuscr. Mannheim: Zentrum für Europäische Wirtschaftsforschung. 
Strasser, D. (1991), Die Finanzen Europas, Luxemburg: Amt für amtliche Veröffentlichungen der EG, 7th ed.

Tabellini, G. (2002), Principles of Policy Making in the European Union: An Economic Perspective, CESifo Forum, Vol. 3, No. 2, pp. 16-22.

Vaubel, R. (2001), Europa-Chauvinismus. Der Hochmut der Institutionen, München: Universitas.

Widgrén M. (1994), Voting power in the EC decision making and consequences of two different enlargements, European Economic Review, 38: 1153-1170.

Wissenschaflicher Beirat beim Bundesministerium für Wirtschaft und Technologie (1999), Neuordnung des Finanzierungssystems der Europäischen Gemeinschaft, BMWi-Dokumentation, Nr. 455, Berlin. 


\title{
CESifo Working Paper Series
}

\author{
(for full list see www.cesifo.de)
}

923 Bernard M.S. van Praag and Adam S. Booij, Risk Aversion and the Subjective Time Discount Rate: A Joint Approach, April 2003

924 Yin-Wong Cheung, Kon S. Lai, and Michael Bergman, Dissecting the PPP Puzzle: The Unconventional Roles of Nominal Exchange Rate and Price Adjustment, April 2003

925 Ugo Trivellato and Anna Giraldo, Assessing the 'Choosiness' of Job Seekers. An Exploratory Approach and Evidence for Italy, April 2003

926 Rudi Dornbusch and Stanley Fischer, International Financial Crises, April 2003

927 David-Jan Jansen and Jakob de Haan, Statements of ECB Officials and their Effect on the Level and Volatility of the Euro-Dollar Exchange Rate, April 2003

928 Mario Jametti and Thomas von Ungern-Sternberg, Assessing the Efficiency of an Insurance Provider - A Measurement Error Approach, April 2003

929 Paolo M. Panteghini and Guttorm Schjelderup, Competing for Foreign Direct Investments: A Real Options Approach, April 2003

930 Ansgar Belke, Rainer Fehn, and Neil Foster, Does Venture Capital Investment Spur Employment Growth?, April 2003

931 Assar Lindbeck, Sten Nyberg, and Jörgen W. Weibull, Social Norms and Welfare State Dynamics, April 2003

932 Myrna Wooders and Ben Zissimos, Hotelling Tax Competition, April 2003

933 Torben M. Andersen, From Excess to Shortage - Recent Developments in the Danish Labour Market, April 2003

934 Paolo M. Panteghini and Carlo Scarpa, Irreversible Investments and Regulatory Risk, April 2003

935 Henrik Jacobsen Kleven and Claus Thustrup Kreiner, The Marginal Cost of Public Funds in OECD Countries. Hours of Work Versus Labor Force Participation, April 2003

936 Klaus Adam, George W. Evans, and Seppo Honkapohja, Are Stationary Hyperinflation Paths Learnable?, April 2003

937 Ulrich Hange, Education Policy and Mobility: Some Basic Results, May 2003 
938 Sören Blomquist and Vidar Christiansen, Is there a Case for Public Provision of Private Goods if Preferences are Heterogeneous? An Example with Day Care, May 2003

939 Hendrik Jürges, Kerstin Schneider, and Felix Büchel, The Effect of Central Exit Examinations on Student Achievement: Quasi-experimental Evidence from TIMSS Germany, May 2003

940 Samuel Bentolila and Juan F. Jimeno, Spanish Unemployment: The End of the Wild Ride?, May 2003

941 Thorsten Bayindir-Upmann and Anke Gerber, The Kalai-Smorodinsky Solution in Labor-Market Negotiations, May 2003

942 Ronnie Schöb, Workfare and Trade Unions: Labor Market Repercussions of Welfare Reform, May 2003

943 Marko Köthenbürger, Tax Competition in a Fiscal Union with Decentralized Leadership, May 2003

944 Albert Banal-Estañol, Inés Macho-Stadler, and Jo Seldeslachts, Mergers, Investment Decisions and Internal Organisation, May 2003

945 Kaniska Dam and David Pérez-Castrillo, The Principal-Agent Matching Market, May 2003

946 Ronnie Schöb, The Double Dividend Hypothesis of Environmental Taxes: A Survey, May 2003

947 Erkki Koskela and Mikko Puhakka, Stabilizing Competitive Cycles with Distortionary Taxation, May 2003

948 Steffen Huck and Kai A. Konrad, Strategic Trade Policy and Merger Profitability, May 2003

949 Frederick van der Ploeg, Beyond the Dogma of the Fixed Book Price Agreement, May 2003

950 Thomas Eichner and Rüdiger Pethig, A Microfoundation of Predator-Prey Dynamics, May 2003

951 Burkhard Heer and Bernd Süssmuth, Cold Progression and its Effects on Income Distribution, May 2003

$952 \mathrm{Yu}-\mathrm{Fu}$ Chen and Michael Funke, Labour Demand in Germany: An Assessment of NonWage Labour Costs, May 2003

953 Hans Gersbach and Hans Haller, Competitive Markets, Collective Decisions and Group Formation, May 2003

954 Armin Falk, Urs Fischbacher, and Simon Gächter, Living in Two Neighborhoods Social Interactions in the LAB, May 2003 
955 Margarita Katsimi, Training, Job Security and Incentive Wages, May 2003

956 Clemens Fuest, Bernd Huber, and Jack Mintz, Capital Mobility and Tax Competition: A Survey, May 2003

957 Edward Castronova, The Price of 'Man' and 'Woman': A Hedonic Pricing Model of Avatar Attributes in a Synthetic World, June 2003

958 Laura Bottazzi and Marco Da Rin, Financing Entrepreneurial Firms in Europe: Facts, Issues, and Research Agenda, June 2003

959 Bruno S. Frey and Matthias Benz, Being Independent is a Great Thing: Subjective Evaluations of Self-Employment and Hierarchy, June 2003

960 Aaron Tornell and Frank Westermann, Credit Market Imperfections in Middle Income Countries, June 2003

961 Hans-Werner Sinn and Wolfgang Ochel, Social Union, Convergence and Migration, June 2003

962 Michael P. Devereux, Measuring Taxes on Income from Capital, June 2003

963 Jakob de Haan, Jan-Egbert Sturm and Bjørn Volkerink, How to Measure the Tax Burden on Labour at the Macro-Level?, June 2003

964 Harry Grubert, The Tax Burden on Cross-Border Investment: Company Strategies and Country Responses, June 2003

965 Kirk A. Collins and James B. Davies, Measuring Effective Tax Rates on Human Capital: Methodology and an Application to Canada, June 2003

966 W. Steven Clark, Using Micro-Data to Assess Average Tax Rates, June 2003

967 Christopher Heady, The 'Taxing Wages' Approach to Measuring the Tax Burden on Labour, June 2003

968 Michael P. Devereux and Alexander Klemm, Measuring Taxes on Income from Capital: Evidence from the UK, June 2003

969 Bernhard Eckwert and Itzhak Zilcha, The Effect of Better Information on Income Inequality, June 2003

970 Hartmut Egger and Josef Falkinger, The Role of Public Infrastructure for Firm Location and International Outsourcing, June 2003

971 Dag Morten Dalen and Trond E. Olsen, Regulatory Competition and Multi-national Banking, June 2003

972 Matthias Wrede, Tax Deductibility of Commuting Expenses and Residential Land Use with more than one Center, June 2003 
973 Alessandro Cigno and Annalisa Luporini, Scholarships or Student Loans? Subsidizing Higher Education in the Presence of Moral Hazard, June 2003

974 Chang Woon Nam, Andrea Gebauer and Rüdiger Parsche, Is the Completion of EU Single Market Hindered by VAT Evasion?, June 2003

975 Michael Braulke and Giacomo Corneo, Capital Taxation May Survive in Open Economies, July 2003

976 Assar Lindbeck, An Essay on Welfare State Dynamics, July 2003

977 Henrik Jordahl and Luca Micheletto, Optimal Utilitarian Taxation and Horizontal Equity, July 2003

978 Martin D. D. Evans and Richard K. Lyons, Are Different-Currency Assets Imperfect Substitutes?, July 2003

979 Thorsten Bayindir-Upmann and Frank Stähler, Market Entry Regulation and International Competition, July 2003

980 Vivek Ghosal, Firm and Establishment Volatility: The Role of Sunk Costs, Profit Uncertainty and Technological Change, July 2003

981 Christopher A. Pissarides, Unemployment in Britain: A European Success Story, July 2003

982 Wolfgang Buchholz, Richard Cornes, and Wolfgang Peters, On the Frequency of Interior Cournot-Nash Equilibria in a Public Good Economy, July 2003

983 Syed M. Ahsan and Panagiotis Tsigaris, Choice of Tax Base Revisited: Cash Flow vs. Prepayment Approaches to Consumption Taxation, July 2003

984 Campbell Leith and Jim Malley, A Sectoral Analysis of Price-Setting Behavior in US Manufacturing Industries, July 2003

985 Hyun Park and Apostolis Philippopoulos, Choosing Club Membership under Tax Competition and Free Riding, July 2003

986 Federico Etro, Globalization and Political Geography, July 2003

987 Dan Ariely, Axel Ockenfels and Alvin E. Roth, An Experimental Analysis of Ending Rules in Internet Auctions, July 2003

988 Paola Conconi and Carlo Perroni, Self-Enforcing International Agreements and Domestic Policy Credibility, July 2003

989 Charles B. Blankart and Christian Kirchner, The Deadlock of the EU Budget: An Economic Analysis of Ways In and Ways Out, July 2003 